Jurnal Informatika dan Rekayasa Perangkat Lunak (JATIKA)
Vol. 1, No. 1, June 2020, 100-108

\title{
AUGMENTED REALITY SEJARAH PAHLAWAN PADA UANG KERTAS RUPIAH DENGAN TEKNOLOGI FACIAL MOTION CAPTURE BERBASIS ANDROID
}

\author{
Nur Miftahul Haq ${ }^{1}$ \\ S1Informatika ${ }^{1}$ (Universitas Teknokrat Indonesia) \\ nurmiftahulhaq@gmail.com ${ }^{1}$
}

\begin{abstract}
Received: (Juni 2020)Accepted: (Juni 2020) Published: (Juni 2020)
\end{abstract}
\begin{abstract}
Learning history functions to make people aware of the process of change and development of society in the time dimension and to build historical perspectives and awareness in finding and understanding events. One of the unforgettable history is Indonesia's independence in 1945. And behind the incident, many Heroes who are very meritorious to liberate Indonesia. The classic problem of learning history in school is the presence of a very strong image among students that history subjects are subjects that are memorized, less interesting, and boring. Then a mobile application will be built that can increase public knowledge about the history of the National Heroes and make money as a media for learning the history of the National Heroes, and it is hoped that this application can add a new experience for users. Augmented reality objects that exist in this application are created by using Facial Motion Capture technology which functions to move the expression on 3 Dimensional characters. This application development methodology uses Lutther which consists of 6 stages, namely concept (conceptualization), design (material design), material collecting (material collection), assembly (making program), testing (distribution) and distribution (distribution). Black Box is one method of software testing that focuses on the functionality, especially on the input and output applications. In the test the results obtained are all the functions contained in the system running well, all descriptions and expected results can run, so that all the results of the test provide a successful assessment with $100 \%$ results
\end{abstract}

Keywords: History, Heroes, Augmented Reality, Multimedia, Android.

\begin{abstract}
Abstrak
Pembelajaran sejarah berfungsi untuk menyadarkan akan adanya proses perubahan dan perkembangnya masyarakat dalam dimensi waktu dan untuk membangun perspektif serta kesadaran sejarah dalam menemukan dan memahami suatu peristiwa. Salah satu sejarah yang tak terlupakan adalah kemerdekaan Indonesia pada tahun 1945. Dan dibalik peristiwa tersebut, banyak PahlawanPahlawan yang sangat berjasa untuk memerdekakan Indonesia. Persoalan klasik pembelajaran sejarah di sekolah adalah adanya image yang sangat kuat di kalangan siswa bahwa mata pelajaran sejarah adalah mata pelajaran yang bersifat hafalan, kurang menarik, dan membosankan. Maka akan dibangun sebuah aplikasi mobile yang dapat menambah pengetahuan masyarakat tentang sejarah Pahlawan Nasional dan menjadikan uang sebagai media pembelajaran sejarah Pahlawan Nasional, dan diharapkan aplikasi ini dapat menambah pengalaman baru bagi pengguna. Objek Augmented reality yang ada pada aplikasi ini dibuat dengan menggunakan teknologi Facial Motion Capture yang berfungsi untuk menggerakan ekspresi pada karakter 3 Dimensi. Metodologi pengembangan aplikasi ini menggunakan Lutther yang terdiri dari 6 tahap yaitu concept (pengonsepan), design (pembuatan desain), material collecting (pengumpulan material), assembly (pembuatan program), testing (pengujian) dan distribution (distribusi).Hasil pengujian aplikasi menggunakan Black Box yaitu adalah salah satu metode pengujian perangkat lunak yang berfokus pada sisi fungsionalitas, khususnya pada input dan output aplikasi. Pada pengujian tersebut hasil yang diperoleh adalah seluruh fungsi yang terdapat pada sistem berjalan dengan baik, semua deskripsi dan hasil yang diharapkan dapat berjalan, sehingga semua hasil dari pengujian memberikan penilaian yang sukses dengan hasil $100 \%$.
\end{abstract}

Kata Kunci: Sejarah, Pahlawan, Augmented Reality, Multimedia, Android. 
To cite this article:

Nur Miftahul Haq, Qadhli Jafar Adrian. (2020). AUGMENTED REALITY SEJARAH PAHLAWAN PADA UANG KERTAS RUPIAH DENGAN TEKNOLOGI FACIAL MOTION CAPTURE BERBASIS ANDROID. Jurnal Informatika dan Rekayasa Perangkat Lunak, Vol(1), 100-108.

\section{PENDAHULUAN}

Pembelajaran sejarah berfungsi untuk menyadarkan akan adanya proses perubahan dan perkembangnya masyarakat dalam dimensi waktu dan untuk membangun perspektif serta kesadaran sejarah dalam menemukan dan memahami suatu peristiwa. Salah satu sejarah yang tak terlupakan adalah kemerdekaan Indonesia pada tahun 1945. Dan dibalik peristiwa tersebut, banyak Pahlawan- Pahlawan yang sangat berjasa untuk memerdekakan Indonesia.

Salah satu perkembangan teknologi lainnya yaitu Augmented Reality (AR) yang merupakan salah satu inovasi teknologi dalam meningkatkan interaksi antara manusia dan mesin. Dengan teknologi AR, suatu benda yang sebelumnya hanya dapat dilihat secara dua dimensi, dapat muncul sebagai obyek virtual yang dimasukkan ke dalam lingkungan nyata secara real-time. Image ini mengindikasikan rendahnya partisipasi siswa dalam proses pembelajaran, atau dari banyak guru yang menggunakan metode ceramah bervariasi tanya jawab. (Sayono, 2013)

Berdasarkan permasalahan tersebut, maka akan dibangun sebuah aplikasi mobile yang dapat meningkatkan pengetahuan masyarakat tentang sejarah Pahlawan Nasional dan menjadikan uang sebagai media pembelajaran sejarah Pahlawan Nasional. Aplikasi ini menggunakan platform android yang memanfaatkan teknologi Augmented Reality dengan menggunakan teknik Facial Motion Capture dalam pembuatannya, dan menggunakan uang kertas Rupiah tahun 2016 sebagai medianya. Aplikasi ini akan menampilkan karakter 3 Dimensi dan informasi mengenai sejarah singkat Pahlawan Nasional yang ada pada uang kertas tersebut.

\section{TELAAH PUSTAKA}

\section{Augmented Reality}

Teknologi Augmented Reality merupakan perkembangan dari Virtual Reality dan bagian dari Mixed Reality. Baik Virtual Environment (Lingkungan Virtual) dan Augmented Virtuality (Virtual terambah), dimana keduanya objek nyata ditambahkan ke bagian virtual. AR menyediakan local virtuality/ virtual sebagian (Krevelen, 2014). Sistem Augmented Reality harus mempunyai ciri sebagai berikut:

1. Mengkombinasikan kenyataan dan objek virtual di lingkungan nyata.

2. Bersifat interaktif, dan di real time(waktu nyata),

3. Menyelaraskan kenyataan dan objek virtual satu dengan lainnya.

\section{Uang Rupiah}

Rupiah adalah mata uang kita. Sebagai alat pembayaran yang sah di republik ini. Selain itu kita juga sepatutnya mengenali ciri-ciri keaslian uang Rupiah. Dengan mengenali ciri-ciri keaslian uang Rupiah, maka diharapkan kita dapat terhindar dari kejahatan pemalsuan uang. Selain uang Rupiah yang kita ketahui, masih ada macam uang khusus, berupa uang kertas bersambung (uncut banknotes) dan koin peringatan (commemorative coins). BANK Indonesia (Indonesia, 2016).

\section{Sejarah Pahlawan Nasional}

Sejarah adalah studi tentang masa lalu, khususnya bagaimana kaitannya dengan manusia. Pembelajaran sejarah berfungsi untuk menyadarkan akan adanya proses perubahan dan perkembangnya masyarakat dalam dimensi waktu dan untuk membangun perspektif serta kesadaran sejarah dalam menemukan dan memahami suatu peristiwa (Agung, 2017)

Kesadaran sejarah merupakan pandangan, pikiran atau konstruksi sejarah sebagai daya upaya yang direncanakan untuk mengerti masa lalu didalam lingkungan sendiri yang berfungsi mengukur dan menentukan sikap manusia dalam kerangka sejarahnya atau historical mindedness. (Gottschalk, 2008)

Pahlawan adalah seorang yang pahala perbuatannya berhasil bagi kepentingan orang banyak. Perbuatannya memiliki pengaruh terhadap tingkah laku orang lain, karena dinilai mulia dan bermanfaat bagi kepentingan masyarakat bangsa atau umat manusia. (Mirnawati, 2010) 


\section{METODELOGI PENELITIAN}

\section{Kerangka Pemikiran}

Kerangka pemikiran merupakan bentuk dari keseluruan proses dalam penelitian. Diawali dengan identifikasi masalah, kemudian usulan solusi, dilanjutkan ke tahap pengembangan, mendapatkan hasil pembahasan dan kesimpulan.

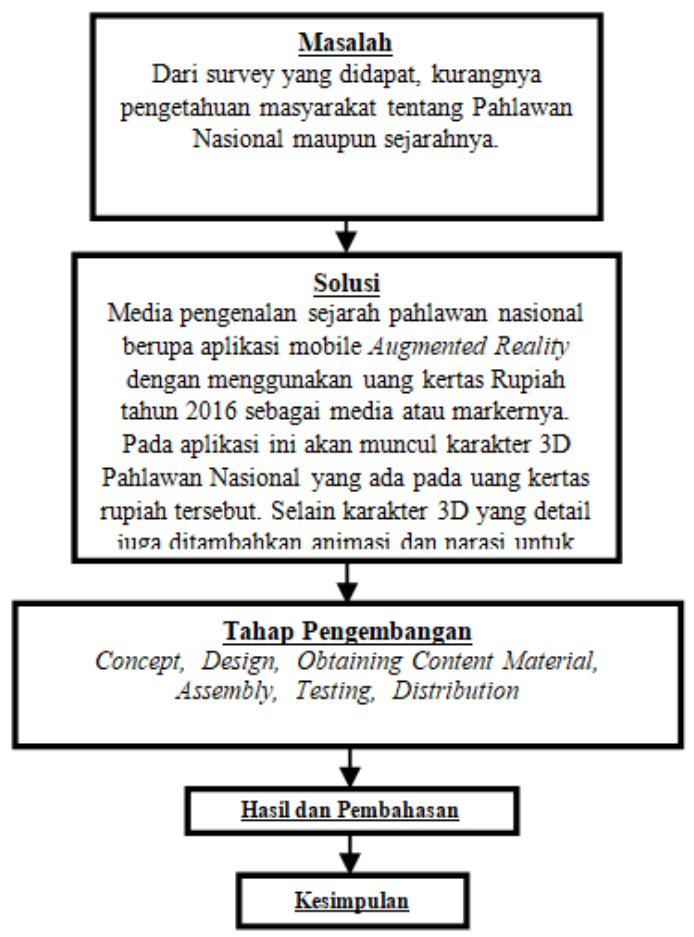

Gambar 1. Kerangka Pemikiran

\section{Teknik Pengumpulan Data}

Teknik pengumpulan data yang dilakukan penulis dalam penelitian ini adalah sebagai berikut :

1) Observasi

Teknik pengumpulan data dengan observasi dilakukan untuk melihat dan mengamati secara langsung subjek penelitian untuk menentukan analisis kebutuhan dari aplikasi yang dikembangkan. Penulis mengamati subjek peneltian dari berita berita yang beredar baik dari media sosial maupun media elektrnik yaitu permasalahan tentang desain uang baru yang akan diedarkan . masyarakat berasumsi bahwa ada beberapa pahlawan tidak pantas untuk menjadi desain mata uang rupiah karna kurang tahunya masyarakat tentang tokoh pahlawan

2) Kajian Pustaka

Kajian pustaka digunakan sebagai referensi dalam menunjang teori-teori atau hal-hal yang berkaitan dengan penelitian yang dilakukan. Yaitu referensi dari beberapa literatur dan informasi pahlawan yang diperoleh dari buku buku pahwalan

3) Kuisioner

Kuisioner merupakan seperangkat pertanyaan yang diberikan kepada responden sebagai alat untuk penilaian. Kuisioner dibagikan kepada responden sebagai alat penilaian tentang seberapa tahunya masyarakat tentang tokoh pahlawan.

\section{Tahapan Pengembagan Multimedia}

Penelitian ini menggunakan tahapan pengembangan Multimedia Development Life Cycle yang terdiri dari enam tahap, yaitu concept, design, obtainingmaterial collecting, assembly, testing, dan distribution (Sutopo, 2003) 
1. $\quad$ Konsep (Concept)

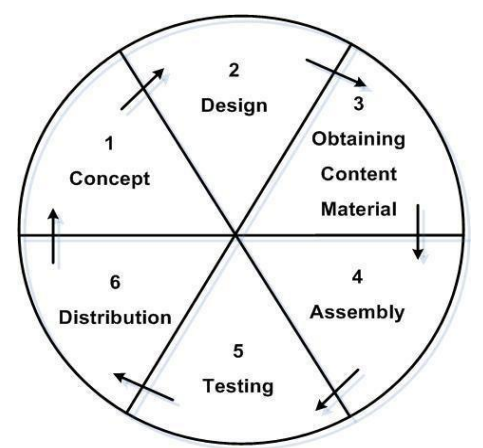

Gambar 2. Tahap Pengembangan Aplikasi Multimedia

Ada beberapa konsep yang dilakukan untuk pembuatan aplikasi ini, untuk menentukan maksud, tujuan, dan sasaran sistem dengan cara menganalisa kebutuhan sistem. Pada tahap ini ditentukan tujuan dari pembuatan aplikasi, serta pengguna. Tujuan dari aplikasi ini adalah merancang media pembelajaran berupa Augmented Reality sejarah Pahlawan Nasional dengan objek karakter 3 Dimensi dengan menggunakan teknologi Facial Motion Capture dan menggunakan uang kertas Rupiah 2016 sebagai media marker nya

2. Perancangan (Design)

Dalam tahapan perancangan (design) ini membuat storyboard aplikasi dan struktur navigasi

3. Pengumpulan Bahan (Obtaining Content Material)

Pada tahap pengumpulan bahan, bahan yang dikumpulkan adalah berupa teks, gambar, 3D Model, suara. Material-material yang digunakan untuk kebutuhan aplikasi diperoleh dari membuat sendiri dengan menggunakan program Adobe Photoshop, Blender 3D, dan Unity 3D

4. Pembuatan (Assembly)

Pada tahap ini, perancangan yang sudah dilakukan kemudian diimplementasikan menjadi aplikasi secara utuh. Semua objek atau elemen multimedia digabungkan menjadi satu dan diintegrasikan menggunakan software Unity 3D.

5. Pengujian (Testing)

Pada penelitian ini tahap testing dilakukan dengan menggunakan pengujian Black Box, yaitu adalah salah satu metode pengujian perangkat lunak yang berfokus pada sisi fungsionalitas, khususnya pada input dan output aplikasi. Tahap pengujian testing merupakan salah satu tahap yang harus ada dalam sebuah siklus pengembangan perangkat lunak

6. Distribusi (Distribution)

Setelah dilakukan pengujian aplikasi dilakukan tahap distribusi. Pada tahap ini, aplikasi diproses dalam pembuatan aplikasi berbentuk apk. Setelah dilakukan proses tersebut, aplikasi didistribusikan pada masyarakat umum pengguna android melalui social media dan Google Play Store.

\section{HASIL DAN PEMBAHASAN}

Hasil dari penelitian ini adalah untuk membangun sebuah Aplikasi Augmented Reality sejarah pahlawan pada uang kertas Rupiah 2016 sebagai markernya, dengan teknologi Facial Motion Capture untuk menggerakan karakter pahlawan tersebut. Aplikasi ini berbasis Android dan menggunakan pengujian Black Box sesuai dengan metode pengembangan yang digunakan.

\section{Implementasi Tampilan Menu Utama}

Menu ini digunakan sebagai menu utama dimana terdapat 4 menu didalamnya. 


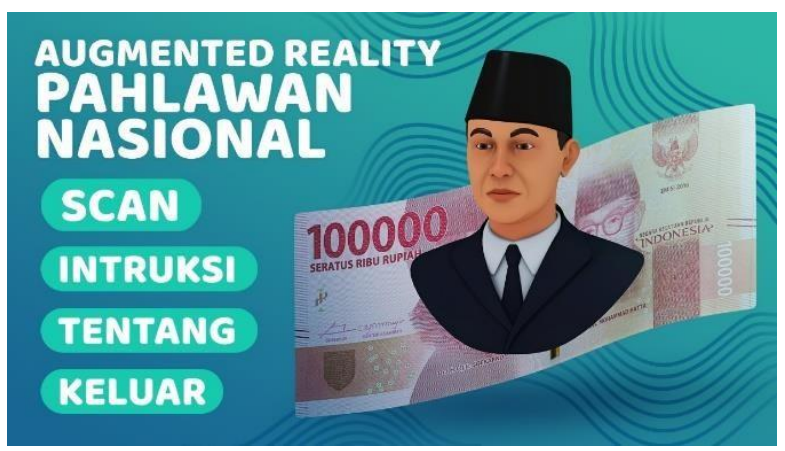

Gambar 3. Implementasi Menu Utama

\section{Implementasi Tampilan Menu Scan}

Setelah user memilih Menu Scan maka muncul tampilan halaman untuk memilih nominal uang yang dimiliki oleh user yang nantinya akan dialihkan ke tampilan kamera, agar uang tersebut dapat di scan oleh aplikasi.

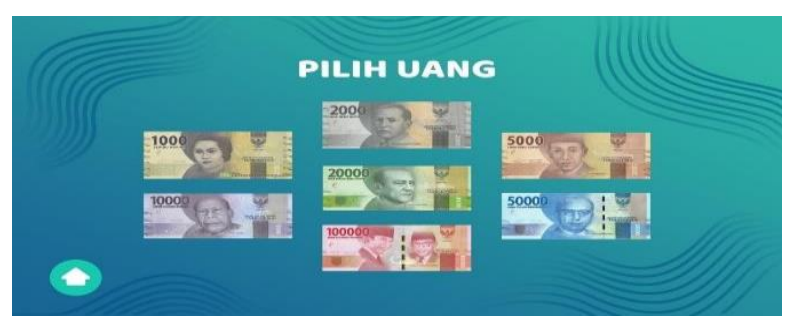

Gambar 4. Implementasi Menu Scan

\section{Implementasi Tampilan Menu Kamera Scan}

Setelah user memilih nominal mata uang, maka muncul tampilan kamera, dan user harus mengarahkan kamera ke atas bagian mata uang yang bergambarkan pahlawan. Maka akan muncul karakter 3D dari pahlawan tersebut. User dapat memutar uang atau kamera secara berlahan untuk dapat melihat sisi lain dari karakter pahlawan tersebut. Didalam halaman kamera ini, terdapat tombol home untuk kembali ke menu utama, tombol uang untuk kembali ke menu pilihan nominal mata uang, dan tombol play yang berfungsi untuk menggerakan karakter berikut dengan suaranya, serta tombol informasi untuk mengetahui sejarah singkat tentang pahlawan tersebut.

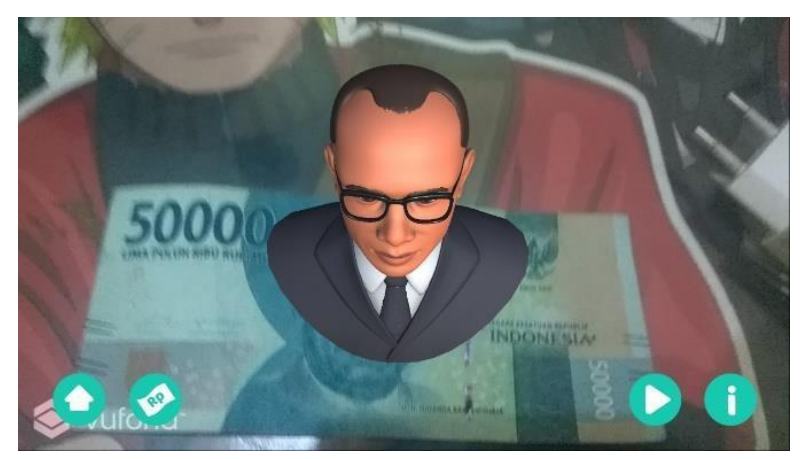

Gambar 5. Implementasi Menu Kamera Scan

\section{Implementasi Tampilan Menu Informasi Sejarah Pahlawan}

Setelah menekan tombol "i" atau informasi, maka akan muncul tampilan sejarah singkat tentang pahlawan, informasi sejarah pahlawan ini didapat dari buku "Kumpulan Sejarah Lengkap Phalawan 
Indonesia oleh S. Tabrani, dan dari buku "Sejarah Lengkap Pahlawan Indonesia oleh Mohammad Murdiono S.Pd. Sejarah dapat dilihat seperti pada gambar berikut :

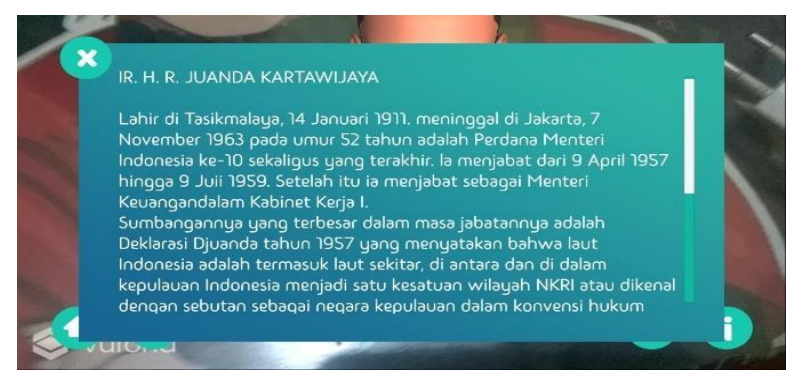

Gambar 6. Implementasi Menu Informasi Sejarah Pahlawan

5. Implementasi Tampilan Menu Intruksi

Pada menu intruksi, user dapat membaca dan mengetahui bagaimana cara menggunakan aplikasi Augmented Reality Sejarah Pahlawan ini.

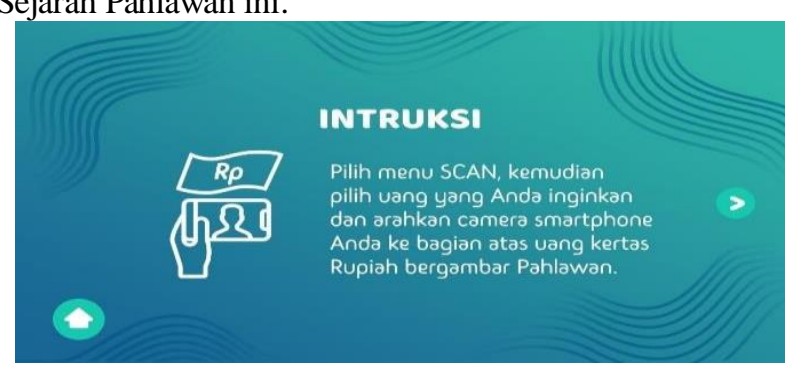

Gambar 7. Implementasi Menu Intruksi

\section{Implementasi Tampilan Menu Tentang}

Pada menu tentang, berisi informasi mengenai aplikasi Augmented Reality Sejarah Pahlawan, tentang pembuat aplikasi dan lain lain.

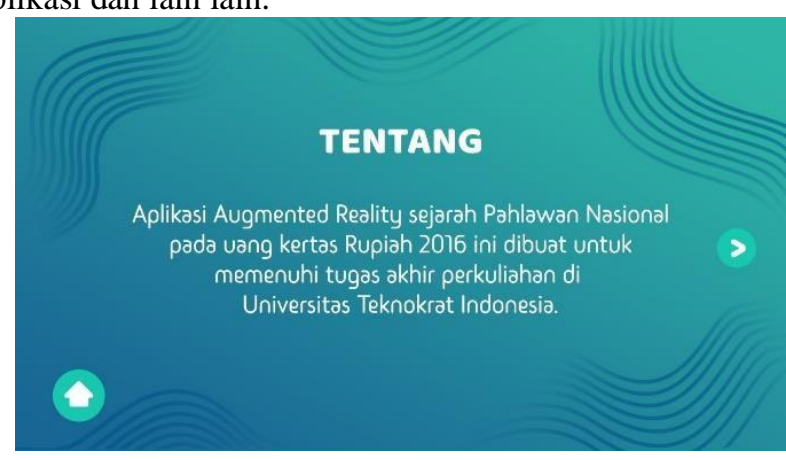

Gambar 8. Implementasi Menu Tentang

\section{Implementasi Tampilan Menu Keluar}

Pada menu keluar terdapat pilihan ya atau tidak, jika user memilih "ya" maka aplikasi akan keluar, jika user memilih "tidak” maka aplikasi akan kembali ke menu utama. 


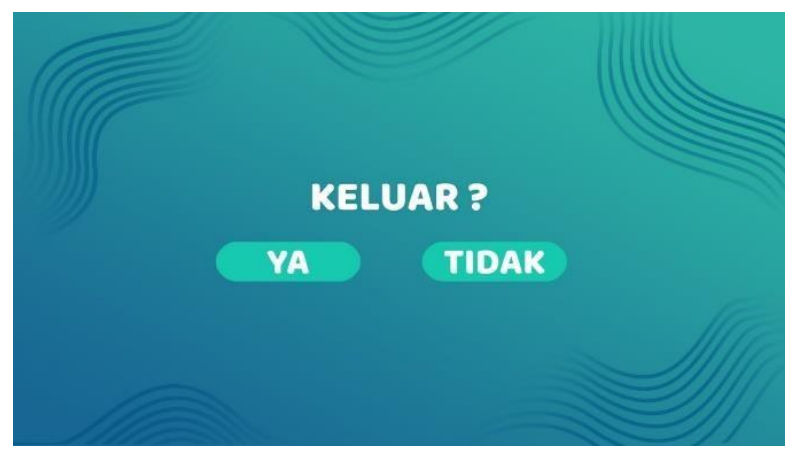

Gambar 9. Implementasi Menu Keluar

\section{PENGUJIAN SISTEM}

Pengujian Black Box adalah salah satu metode pengujian perangkat lunak yang berfokus pada sisi fungsionalitas, khususnya pada input dan output aplikasi. Tahap pengujian testing merupakan salah satu tahap yang harus ada dalam sebuah siklus pengembangan perangkat lunak.

Tabel 1. Pengujian

\begin{tabular}{|c|c|c|c|c|c|}
\hline \multirow{2}{*}{$\begin{array}{c}\begin{array}{c}\text { Test } \\
\text { Case } \\
\text { Name }\end{array} \\
\text { Test ID }\end{array}$} & \multicolumn{5}{|c|}{$\begin{array}{l}\text { Aplikasi Augmented Reality Sejarah Pahlawan Pada Uang Kertas Rupiah Dengan Teknologi } \\
\text { Facial Motion Capture Berbasis Android }\end{array}$} \\
\hline & Deskripsi & $\begin{array}{l}\text { Hasil Yang } \\
\text { Diharapkan }\end{array}$ & $\begin{array}{c}\text { Hasil } \\
\text { Pengamatan }\end{array}$ & Kesimpulan & Keterangan \\
\hline \multicolumn{6}{|c|}{ 1. Menu Utama } \\
\hline 1.1 & $\begin{array}{l}\text { User membuka } \\
\text { aplikasi AR Pahlawan }\end{array}$ & $\begin{array}{l}\text { Menampilkan menu } \\
\text { utama }\end{array}$ & & \begin{tabular}{|l}
$(\checkmark)$ Pass \\
$(\quad)$ Fail
\end{tabular} & \\
\hline \multicolumn{6}{|c|}{ 2. Menu Scan } \\
\hline 2.1 & $\begin{array}{l}\text { User klik tombol } \\
\text { Scan }\end{array}$ & $\begin{array}{l}\text { Menampilkan } \\
\text { pilihan pahlawan } \\
\text { sesuai nominal } \\
\text { rupiah } \\
\end{array}$ & & $\begin{array}{l}(\checkmark) \text { Pass } \\
(\quad) \text { Fail }\end{array}$ & \\
\hline 2.2 & $\begin{array}{l}\text { User memilih } \\
\text { nominal (1000- } \\
100000)\end{array}$ & $\begin{array}{l}\text { Menampilkan } \\
\text { tampilan kamera } \\
\text { untuk men scan } \\
\text { uang Rupiah } \\
\end{array}$ & & $\begin{array}{l}(\checkmark) \text { Pass } \\
(\quad) \text { Fail }\end{array}$ & \\
\hline 2.3 & $\begin{array}{l}\text { User klik tombol } \\
\text { Home }\end{array}$ & $\begin{array}{l}\text { Kembali ke menu } \\
\text { awal }\end{array}$ & & $\begin{array}{l}(\checkmark) \text { Pass } \\
(\quad) \text { Fail }\end{array}$ & \\
\hline 2.4 & User klik tombol Rp & $\begin{array}{l}\text { Menampilkan menu } \\
\text { pilihan pahlawan }\end{array}$ & & $\begin{array}{l}(\checkmark) \text { Pass } \\
(\quad) \text { Fail } \\
\end{array}$ & \\
\hline 2.5 & User klik tombol Play & $\begin{array}{l}\text { Untuk memulai } \\
\text { Gerakan animasi } \\
\text { dan narasi }\end{array}$ & & $\begin{array}{l}(\checkmark) \text { Pass } \\
(\quad) \text { Fail }\end{array}$ & \\
\hline 2.6 & User klik tombol Info & $\begin{array}{l}\text { Untuk menampilkan } \\
\text { informasi singkat } \\
\text { tentang pahlawan }\end{array}$ & & $\begin{array}{l}(\checkmark) \text { Pass } \\
(\quad \text { ) Fail }\end{array}$ & \\
\hline
\end{tabular}


Tabel 2. Pengujian Sistem

\begin{tabular}{|c|l|l|l|l|l|}
\hline $\begin{array}{c}\text { Test } \\
\text { Case } \\
\text { Name }\end{array}$ & Aplikasi Augmented Reality Sejarah Pahlawan Pada Uang Kertas Rupiah Dengan Teknologi \\
Facial Motion Capture Berbasis Android
\end{tabular}

Pahlawan Pada Uang Kertas Rupiah Dengan Teknologi Facial Motion Capture Berbasis Android. Pengujian dilakukan pada setiap fungsi sistem dengan hasil pengujian sebagai berikut :

$\mathrm{X}$ : Pass

Y: Pengujian

$$
\text { Hasil }=\frac{X}{Y} \times 100 \%
$$

Hasil Testing $(\%)=\frac{20}{20} \times 100 \%$

Hasil $=100 \%$

Pada pengujian black box hasil yang diperoleh adalah seluruh fungsi yang terdapat pada sistem berjalan dengan baik, semua deskripsi dan hasil yang diharapkan dapat berjalan, sehingga semua hasil dari pengujian memberikan penilaian yang sukses dengan hasil 100\%, dari hasil kesimpulan yang memberikan nilai pass (lulus).

\section{SIMPULAN}

Berdasarkan pembahasan dan evaluasi dari, maka dapat diperoleh beberapa kesimpulan sebagai berikut:

1. Untuk merancang Aplikasi Augmented Reality Sejarah Pahlawan Pada Uang Kertas Rupiah Dengan Teknologi Facial Motion Capture Berbasis Android terdapat beberapa tahapan pengembangan, keseluruhan tahapan disusun secara berurutan dimulai dari menganalisis, membuat desain aplikasi, membuat material collecting berupa objek 3 Dimensi, yang digerakan dengan menggunakan teknik facial motion capture dan dilakukan penggabungan seluruh material (coding) menggunakan tools Unity 3D, sebagai acuan pembangun perangkat lunak hingga menjadi produk akhir. 
2. Dari hasil data pengujian BlackBox memberikan penilaian yang sukses dengan hasil 100\%, yang dapat disimpulkan bahwa semua fungsi pada Aplikasi Augmented Reality Sejarah Pahlawan Pada Uang Kertas Rupiah Dengan Teknologi Facial Motion Capture Berbasis Android ini dapat dijalankan dengan baik dan mampu dijadikan sebagai media pengenalan sejarah pahlawan Nasional.

\section{UCAPAN TERIMA KASIH}

Pada bagian ini, penulis menyampaikan ucapan terima kasihnya kepada sumber pendanaan atau bantuan yang diterima, dan pihak lain memainkan peran penting dalam melaksanakan studi Anda dan / atau menyiapkan naskah jika ada sebelum referensi.

\section{REFERENSI/DAFTAR PUSTAKA}

Azuma. (1997). A Survey of Augmented. Reality," Presence: Teleoperators and Virtual Environments, 35.

Apriyani, M. E. (2015). Augmented Reality sebagai Alat Pengenalan Hewan Purbakala dengan Animasi 3D menggunakan Metode Single Marker. Politeknik Negeri Batam, 44.

Govillkar. (2015). Comporative Study Of Augmented Reality. Internatinal Jurnal, 7.

Maturidi, A. (2014). Metode Penelitian Tekhnik Informatika. Deepublish.

Rahmanto, Y., Utama, R. Y. 2018. Penerapan Teknologi Web3D Berbasis Android sebagai Media Pembelajaran Gerakan Dasar Silat - Jurnal TAM (Technology Acceptance Model).

Saputra, V., H. Darwis, D., Febrianto, E. 2020. Rancang Bangun Aplikasi Game Matematika Untuk Penyandang Tunagrahita Berbasis Mobile - Jurnal Komputer dan Informatika.

Sayono, J. (2013). Pembelajaran sekolah dari prakmatis ke Idealis. FIS UNM, 12.

Sutopo, A.H., 2003, Multimedia Interaktif Dengan Flash. Yogyakarta: Graha Ilmu.

Tabrani, (2015). Kumpulan Sejarah Lengkap Pahlawan Indonesia, Bintang Indonesia Jakarta.

Widiansyah, F. (2006). Implementasi AR Pengenalan Arca menggunakan metode Pattern Recognit. Unicom, 36. 